\title{
Degradation of CNP, a Diphenyl Ether Herbicide, in Flooded Soil under Oxidative and Reductive Conditions*
}

\author{
Masami OyamadA** and Shozo Kuwatsuka \\ Department of Agricultural Chemistry, Nagoya University, Nagoya 464, Japan
}

(Received November 20, 1978)

\begin{abstract}
Degradation of CNP, 2,4,6-trichlorophenyl 4'-nitrophenyl ether, in a flooded soil under oxidative (aerobic) and reductive (anaerobic) conditions was studied in the laboratory using ${ }^{14} \mathrm{C}-\mathrm{CNP}$ labelled at each of the benzene rings. The degradation rate of CNP differed depending upon the redox potential of the soil. The half-life period was 6 to 7 days under oxidative conditions and 1 to 2 days under reductive conditions. Degradation of $\mathrm{CNP}$ under oxidative conditions started after a short lag-period. The degradation products were identified as 2,4,6-trichlorophenyl $4^{\prime}$ aminophenyl ether, 2,4,6-trichlorophenyl 4'-acetylaminophenyl ether, 2,4,6-trichlorophenyl 4'-hydroxyphenyl ether, 2,4,6-trichlorophenol, $p$-nitrophenol, and $p-$ aminophenol by $t l c$. Major products were the acylamino derivatives which under reductive conditions reached about $15.5 \%$ of applied radioactivity after 2 days and then decreased thereafter. The other products were detected only in small amounts. Most of the radioactivity was strongly adsorbed to the soil within a few days and was unextractable with organic solvents. This was attributed to complex formation between the amino derivative and soil constituents. More ${ }^{14} \mathrm{CO}_{2}$ was liberated under oxidative, than reductive, flooded conditions.
\end{abstract}

\section{INTRODUCTION}

Diphenyl ether herbicides such as CNP, nitrofen and chlomethoxynil are extensively used as pre-emergence herbicides in paddy fields in Japan and other Asian countries. The amount of CNP (2,4,6-trichlorophenyl 4'nitrophenyl ether) consumed has been the largest among all pesticides used in Japan during the past several years.

Investigations on the degradation of diphenyl ether herbicies such as fluorodifen, ${ }^{2)} \mathrm{CNP},{ }^{3)}$ chlomethoxynil $^{3)}$ and bifenox ${ }^{4}$ in soil have been reported. Degradation of CNP, nitrofen, chlomethoxynil and CFNP (2,4-dichloro-6-

* Most part of this study was presented at the Meeting of the Society of Science of Soil and Manure, Japan, 1974.1)

** Visiting researcher from Agricultural Research Laboratory, Mitsui Toatsu Chemicals Inc., 500 Nishikubo, Chigasaki, Kanagawa 253, Japan (Present Address) fluorophenyl $4^{\prime}$-nitrophenyl ether) in soils were much faster under flooded, than upland, conditions. ${ }^{3)}$ Their half-life periods ranged from 6 to 20 days under flooded conditions but more than 50 days under upland conditions. These compounds were rapidly converted to their amino derivatives in flooded soils. The persistence of fluorodifen in upland soils ${ }^{2)}$ and $\mathrm{CNP}^{5-7)}$ in paddy fields have also been investigated. Considerable amounts of amino derivatives remained in paddy soils, and were extracted from soil after heating in a conc. alkali solution. ${ }^{8)}$

In this study the degradation of $\mathrm{CNP}$ in a soil under oxidative and reductive flooded conditions was investigated in the laboratory experiments using ${ }^{14} \mathrm{C}-\mathrm{CNP}$. Degradation products in the soil is also reported. The absorption and metabolism of CNP and its amino derivative in rice plant was already reported by Shimotori and Kuwatsuka. ${ }^{9)}$ 


\section{MATERIALS AND METHODS}

\section{Radioactive CNP}

Two radioactive samples of ${ }^{14} \mathrm{C}-\mathrm{CNP}, 2,4,6$ trichloro- ${ }^{14} \mathrm{C}$-phenyl $4^{\prime}$-nitrophenyl ether (ring $\mathrm{A}-{ }^{14} \mathrm{C}$ ) and 2,4,6-trichlorophenyl $4^{\prime}-$ nitro- ${ }^{14} \mathrm{C}$ phenyl ether (ring $\mathrm{B}-{ }^{14} C$ ) were synthesized in Daiichi Pure Chemicals Co. Ltd., and kindly supplied by Mitsui Toatsu Chemicals Inc. No radioactive impurity of the sample of ring $\mathrm{B}_{-}$ ${ }^{14} \mathrm{C}-\mathrm{CNP}$ was found on thin layer chromatogram. The sample of ring $\mathrm{A}-{ }^{14} \mathrm{C}-\mathrm{CNP}$ containing small amounts of radioactive impurities was purified by thin layer chromatography using silica gel plate and $n$-hexane : ethyl acetate $(3: 2 \mathrm{v} / \mathrm{v})$. The specific activity of ring $\mathrm{A}-{ }^{14} \mathrm{C}-\mathrm{CNP}$ and ring $\mathrm{B}-{ }^{14} \mathrm{C}-\mathrm{CNP}$ were $0.96 \mathrm{mCi} / \mathrm{mmol}$ and $0.70 \mathrm{mCi} / \mathrm{mmol}$, respectively, and the radioactive purity of both samples was more than $99.9 \%$ determined by the dilution method.

\section{Non-radioactive Chemicals}

Non-radioactive compounds of $\mathrm{CNP}, \mathrm{mp}$ $106-7^{\circ} \mathrm{C}$, with $99.9 \%$ of purity, the amino derivative (CNP-NH$, 2,4,6$-trichlorophenyl $4^{\prime}$-amino phenyl ether), mp $108-9^{\circ} \mathrm{C}$, with $99.9 \%$ of purity, the acetylamino derivative (CNP-NHCOCH 3 , 2,4,6-trichlorophenyl 4'-acetylaminophenyl ether), mp $214-5^{\circ} \mathrm{C}$, the hydroxy derivative (CNP-OH, 2,4,6-trichlorophenyl $4^{\prime}$-hydroxyphenyl ether), mp $137-8^{\circ} \mathrm{C}$, and the azo-compounds $(\mathrm{CNP}-\mathrm{N}=\mathrm{N}-\mathrm{CNP}$, $p, p^{\prime}$-bis(2,4,6-trichlorophenoxy) azobenzene, $\mathrm{mp} 285-7^{\circ} \mathrm{C}$, and $p, p^{\prime}$-hydroxy azobenzene, mp $215-6^{\circ} \mathrm{C}$ ) were supplied by Mitsui Toatsu Chemicals Inc. 2,4,6-Trichlorophenol, $p$-nitrophenol and $p$-aminophenol were obtained commercially. Synthetic methods of these compounds are reported elsewhere. ${ }^{10)}$

\section{Soil Sample}

The soil used was sampled from the plough layer of a paddy rice field in Paddy Field Experimental Farm of Aichi-ken Agricultural Research Center, at Anjo, Aichi Prefecture in October 1973, finely crushed, passed through a $2 \mathrm{~mm}$ sieve, and stored at $4^{\circ} \mathrm{C}$.

The incubation experiments were performed by the early summer of 1974 . The physicochemical properties of the soil were as follows: kaolin clay mineral, clay content $45.2 \%$, light clay, maximum water holding capacity $53.5 \%$, $\mathrm{pH}\left(\mathrm{H}_{2} \mathrm{O}\right) 6.2$, total carbon $1.75 \%$, total nitrogen $0.15 \%$, cation exchange capacity 10.0 m.e./ $100 \mathrm{~g}$.

\section{Soil Conditioning \\ 4.1 Oxidative flooded conditions}

Fifty grams (oven-dried weight basis) of the soil sample in a 500-ml Erlenmeyer flask was flooded with water up to $1 \mathrm{~cm}$ deep and its soil layer was $5 \mathrm{~mm}$ deep. The mouth of the flask was covered with alminum foil and the soil was pre-incubated at $30^{\circ} \mathrm{C}$ in the dark for 5 weeks. Redox potential of the incubated soil ( $\mathrm{pH} 6)$ was $+650 \mathrm{mV}$, and was kept constant throughout the whole incubation period.

\subsection{Reductive flooded conditions}

Fifty grams of the soil sample was placed in a test tube $(20 \mathrm{~cm} \times 3 \mathrm{~cm}$ i.d. $)$. The soil was submerged with water up to $1 \mathrm{~cm}$ deep and the soil layer was $90 \mathrm{~mm}$ deep. The mouth of the test tube was capped with alminum foil and the soil was pre-incubated in the same way as described for the oxidative condition. The redox potential of incubated soil at $\mathrm{pH} 6$ was $-250 \mathrm{mV}$, and was kept constant throughout the incubation period.

\section{Application of ${ }^{14} C-C N P$ and Incubation}

Each of ring $\mathrm{A}-{ }^{14} \mathrm{C}-\mathrm{CNP}\left(33.8 \times 10^{5} \mathrm{dpm}\right)$ and ring $\mathrm{B}-{ }^{14} \mathrm{C}-\mathrm{CNP}\left(25.0 \times 10^{5} \mathrm{dpm}\right)$ dissolved in $0.5 \mathrm{ml}$ of acetone was mixed well with the pre-incubated soil at a concentration of $10 \mathrm{ppm}$ on dry soil basis.

For the absorption of released ${ }^{14} \mathrm{CO}_{2}$, a vial containing $5-\mathrm{ml}$ solution of $4 \mathrm{~N} \mathrm{KOH}$ was placed in the soil. The mouth of the flask or test tube was capped with alminum foil, and the soil was incubated under the same conditions as described for the pre-incubation conditions described above for $1 \mathrm{hr}, 2,5,10$ and 20 days.

\section{Extraction of Radioactive Compounds}

The incubated soil was transferred into a $300-\mathrm{ml}$ bottle, and $100 \mathrm{ml}$ of acetone was added. The bottle was shaken for $1 \mathrm{hr}$. The soil was filtered with glass filter $(G-4)$, and washed twice with $50 \mathrm{ml}$ portions of acetone. The filtrate was combined and the acetone was 
distilled off by concentration using a rotary evaporator. The residual water was extracted three times with $50 \mathrm{ml}$ portion of ether. The extracted solutions and ${ }^{14} \mathrm{CO}_{2}$ absorbed by the $4 \mathrm{~N} \mathrm{KOH}$ solution were subjected to radioassay. The soil residue was also radioassayed by the wet combustion method. ${ }^{11}$

\section{Radioassay}

Radioactivity of the extracted solution was measured in $10 \mathrm{ml}$ of dioxane liquid scintillator and for ${ }^{14} \mathrm{CO}_{2}$ in Bray's scintillator (PPO $4 \mathrm{~g}$, POPOP $0.2 \mathrm{~g}$, naphthalene $60 \mathrm{~g}$, methanol $100 \mathrm{ml}$, ethyleneglycol $20 \mathrm{ml}$, and dioxane, to make $1000 \mathrm{ml}$ ), using a liquid scintillation spectrometer, Packard Model 3350. The quenching was determined by the external standard method.

\section{Thin Layer Chromatography}

Ether extracts from the soil were dried with anhydrous sodium sulfate and concentrated. An aliquot of each concentrated solution was spotted on silica gel plate (Merck $60 \mathrm{~F}$ 254, precoated, $0.25 \mathrm{~mm}$ thick, $20 \times 20 \mathrm{~cm}$ ) and reference compounds disolved in acetone were spotted over the sample spot. The plates were developed using two dimensional chromatography with $n$-hexane-ethyl acetate $(2: 1 \mathrm{v} / \mathrm{v})$ for the first development and chloroform for the second one, and $n$-hexane for the third one to the same direction as the second one. Other solvent systems were also used, if necessary. $R f$ values of the reference compounds are shown in Table 1. Spots of the reference compounds were detected by irradiation with ultraviolet rays $(254 \mathrm{~nm})$, and the radioactive spots were detected by radioautograms on X-ray films (Fuji Kx, Medical).

\section{RESULTS AND DISCUSSION}

Figure 1 shows change with time in the radioactivity in each fraction. The radioactivity of each fraction extremely differed between oxidative conditions and reductive conditions of the flooded soil. The difference in degradation products between ring $\mathrm{A}-{ }^{14} \mathrm{C}-\mathrm{CNP}$ and ring $\mathrm{B}-$ ${ }^{14} \mathrm{C}-\mathrm{CNP}$ were hardly observed except $2,4,6-$ trichlorophenol and $p$-nitrophenol. The degradation rate of CNP was largely different between both redox conditions of soil. In the oxidative flooded soil the degradation started after a short lag-period and the half-life period of $\mathrm{CNP}$ was 6 to 7 days. On the other hand, no lag period was observed under reductive conditions and the half-life was 1 to 2 days. The radioactivity of the degradation products of ${ }^{14} \mathrm{C}-\mathrm{CNP}$ in ether-soluble fractions reached about 30 to $35 \%$ of applied radioactivity after 10 days under oxidative flooded conditions, about 55 to $60 \%$ after 2 to 5 days under reductive conditions, and then decreased.

The acetone unextractable radioactivity remaining in the soil, originated from both ring $\mathrm{A}-{ }^{14} \mathrm{C}-\mathrm{CNP}$ and ring $\mathrm{B}-{ }^{14} \mathrm{C}-\mathrm{CNP}$, and increased slowly to reach about 35 to $40 \%$ after 10 to 20 days under oxidative flooded conditions. Under reductive conditions, the retained radioactivity

Table $1 R f$ values of CNP and the reference compounds.

\begin{tabular}{lcccccccc}
\hline \multirow{2}{*}{ Compounds } & \multicolumn{7}{c}{ Solvent systems $^{\mathrm{a}}$} \\
\cline { 2 - 8 } & $\mathrm{A}$ & $\mathrm{B}$ & $\mathrm{C}$ & $\mathrm{D}$ & $\mathrm{E}$ & $\mathrm{F}$ & $\mathrm{G}$ \\
\hline CNP & 0.84 & 0.78 & 0.85 & 0.86 & 0.70 & - & - \\
2,4,6-Trichlorophenyl 4'-aminophenyl ether & 0.59 & 0.48 & 0.64 & 0.69 & 0.11 & - & - \\
2,4,6-Trichlorophenyl 4'-acetylaminophenyl ether & 0.19 & 0.15 & 0.32 & 0.38 & 0 & - & - \\
2,4,6-Trichlorophenyl 4'-hydroxyphenyl ether & 0.67 & 0.28 & 0.65 & 0.60 & 0.06 & - & - \\
$p, p^{\prime}$-Bis(2,4,6-trichlorophenoxy)azobenzene & 0.86 & 0.82 & 0.90 & 0.91 & 0.81 & - & - \\
p,p'-Hydroxy axobenzene & 0.31 & 0.01 & 0.21 & 0.34 & 0 & - & - \\
2,4,6-Trichlorophenol & 0.72 & 0.44 & 0.53 & 0.70 & 0.32 & - & - \\
-Nitrophenol & 0.52 & 0.17 & 0.49 & 0.41 & 0.02 & 0.76 & 0.68 \\
p-Aminophenol & 0.06 & 0.02 & 0.09 & 0.11 & 0 & 0.56 & 0.28 \\
\hline
\end{tabular}

a) Solvent systems: A, $n$-hexane-ethyl acetate $(2: 1 \mathrm{v} / \mathrm{v})$; B, chloroform; C, benzene-chloroform-acetone $(7: 2: 1 \mathrm{v} / \mathrm{v})$; D, benzene-methanol-acetic acid $(45: 5: 1 \mathrm{v} / \mathrm{v}) ; \mathrm{E}, n$-hexanetoluene $(1: 1 \mathrm{v} / \mathrm{v}) ; \mathrm{F}$, benzene-acetone $(3: 1 \mathrm{v} / \mathrm{v}) ; \mathrm{G}$, chloroform-acetone $(1: 1 \mathrm{v} / \mathrm{v})$. 

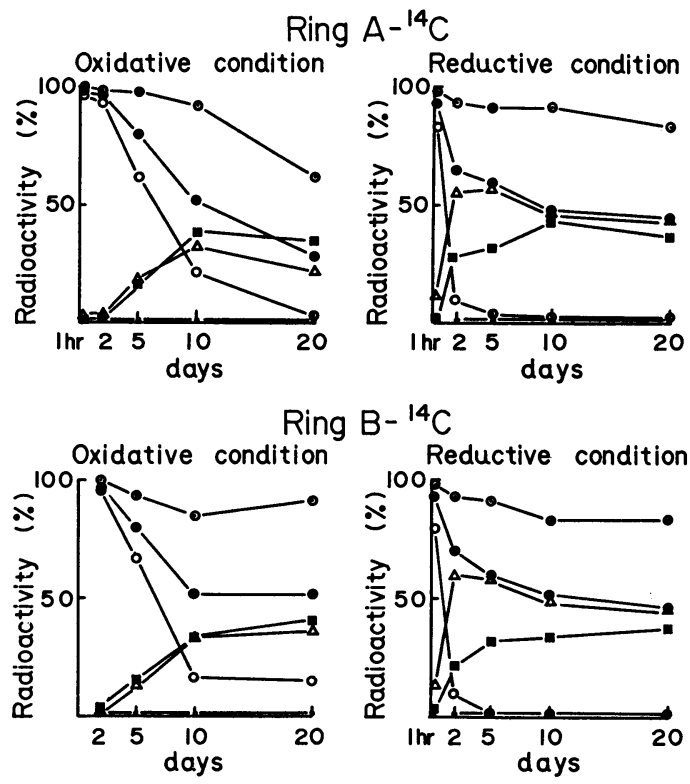

Fig. 1 Change in radioactivity of various fractions during ${ }^{14} \mathrm{C}-\mathrm{CNP}$ degradation in soil.

○ total radioactivity, - ether-extractable,

- water-soluble, $\boldsymbol{\square}$ unextractable from soil,

$\bigcirc \mathrm{CNP}, \triangle$ total ether-extractable metabolites

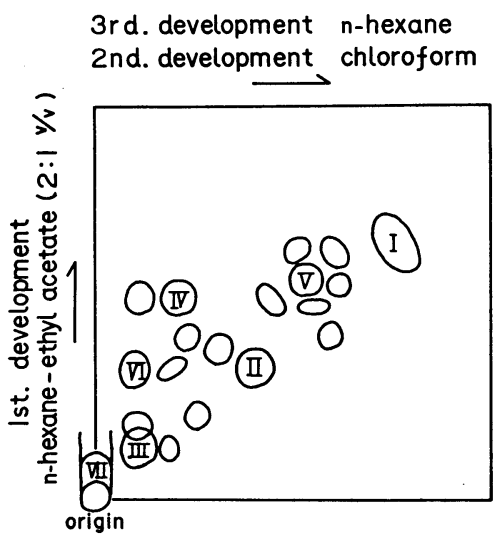

Fig. 2 Thin-layer chromatogram of etherextracts of ${ }^{14} \mathrm{C}-\mathrm{CNP}$ degradation products in soil.

[I] $\mathrm{CNP},[\mathrm{II}] \mathrm{CNP}-\mathrm{NH}_{2},[\mathrm{III}] \mathrm{CNP}-\mathrm{NH}-$ $\mathrm{COCH}_{3}$, [IV] CNP-OH, [V] 2,4,6-trichlorophenol, [VI] $p$-nitrophenol, [VII] $p$-aminophenol

Numerals in brackets shows the same numbers for chemical structure in Fig. 5 . increased rapidly within 2 days and reached a maximum after 5 to 10 days. Radioactivity of the acetone-extracts was almost soluble in ether. The radioactivity of water-soluble fractions in acetone extracts was relatively small in all cases.

The radioautograms of the ether extracts on tlc (Fig. 2) revealed CNP (1), the amino derivative $\left(\mathrm{CNP}-\mathrm{NH}_{2}, \mathrm{II}\right)$, the acetylamino derivative $\left(\mathrm{CNP}-\mathrm{NHCOCH}_{3}, \mathrm{III}\right)$, the hydroxy derivative (CNP-OH, IV), 2,4,6-trichlorophenol (V), $p$ nitrophenol (VI), $p$-aminophenol (VII), and several unidentified products.

Among these compounds $\mathrm{CNP}-\mathrm{NHCOCH}_{3}$ was most abundant. However, the acetylamino derivative was not clearly separated from a minor unidentified product by several solvent systems tested. Therefore, these were scraped off together from the $t l c$ plate and the total radioactivity was measured. The unidentified product was presumed to be the formylamino derivative of $\mathrm{CNP}$ (CNP-NHCHO) from the relative $R f$ values on $t l c$ of the acetylamino and formylamino derivatives of chlomethoxynil. ${ }^{3)}$

$p$-Nitrophenol and $p$-aminophenol was separated clearly by $t l c$ with the solvent systems $\mathrm{F}$ and $\mathrm{G}$ in Table 1. $p, p^{\prime}-\mathrm{Bis}(2,4,6-$ trichlorophenoxy) azobenzene had a similar $R f$-value as the other unknown product using solvent systems $F$ and $G$, but this product was not identical with the azocompound on $t l c$ using the other solvent systems (A-E). $p, p^{\prime}-$ Hydroxy azobenzene was not detected.

The change in amount of the acetylamino derivative containing the minor unidentified product presumed to be $\mathrm{CNP}-\mathrm{NHCHO}$ was more rapidly produced under reductive, than oxidative, flooded conditions, by incubating with both ${ }^{14} \mathrm{C}$-CNP labelled samples (Fig. 3). These acylamino derivatives of CNP were produced in greater amounts than the acylamino derivatives of chlomethoxynil. Especially, under reductive flooded conditions, the amounts of the acylamino derivatives from CNP was 3 to 5 times of those from chlomethoxynil. These results seem to indicate that the acylamino derivatives of chlomethoxynil are degraded additively by demethylation of the methoxy group.

Each of $\mathrm{CNP}-\mathrm{NH}_{2}, \quad \mathrm{CNP}-\mathrm{OH}, 2,4,6$-trichlorophenol and $\mathrm{CO}_{2}$ was produced in larger 

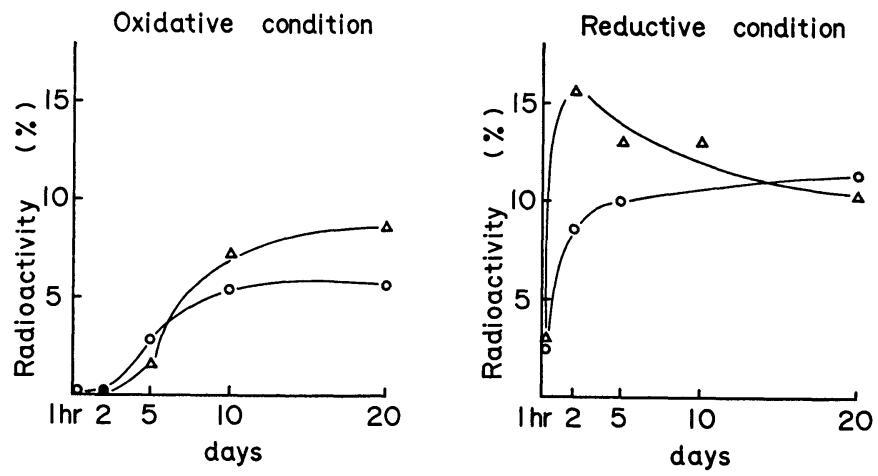

Fig. 3 Change in amount of the acetylamino derivative containing a small amount of an unidentified product.

ring $\mathrm{A}-{ }^{14} C, \triangle$ ring $\mathrm{B}-{ }^{14} C$
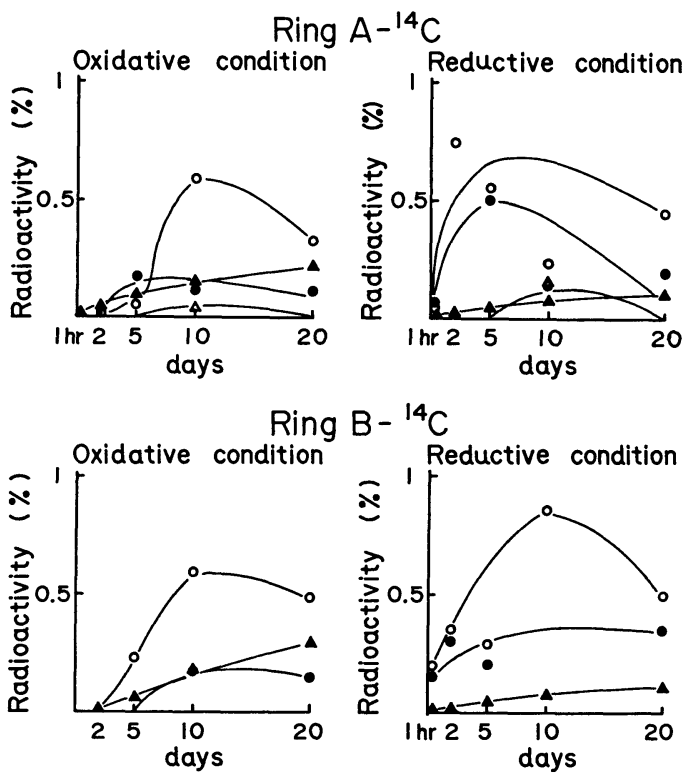

Fig. 4 Change in amounts of $\mathrm{CNP}-\mathrm{NH}_{2}$, $\mathrm{CNP}-\mathrm{OH}, 2,4,6$-trichlorophenol, and $\mathrm{CO}_{2}$.

O $\mathrm{CNP}-\mathrm{NH}_{2},-\mathrm{CNP}-\mathrm{OH}, \Delta \mathrm{CO}_{2}, \Delta 2,4,6-$ trichlorophenol

amount under reductive flooded conditions than oxidative conditions, but the amounts did not exceed $1 \%$ in all cases (Fig. 4). The amount of $\mathrm{CNP}-\mathrm{NH}_{2}$ recovered was extremely smaller than that reported in a previous study, in which $\mathrm{CNP}-\mathrm{NH}_{2}$ was extracted with hot conc. alkali solution from the soil. ${ }^{8)}$ It is presumed that $\mathrm{CNP}-\mathrm{NH}_{2}$ is present as complexes between the amino group and soil constituents. It was also determined in previous studies. ${ }^{12,13)}$ The amount of $\mathrm{CNP}-\mathrm{NH}_{2}$ shown in Fig. 4 may result only from the quantity of "free" amino derivative in the soil. The complex or the "Bound residue" of $\mathrm{CNP}-\mathrm{NH}_{2}$ is reported elsewhere. ${ }^{12)} \mathrm{CNP}-\mathrm{OH}$ was produced in larger amount under reductive, than oxidative, flooded conditions in amounts less than $0.5 \%$ of applied radioactivity. The amount of 2,4,6trichlorophenol produced was less than $0.2 \%$. $p$-Nitrophenol and $p$-aminophenol were detected only in trace amounts. The other unidentified products in the ether-extracts were recovered in small amounts. No products accumulated in the ether-extractable fraction. ${ }^{14} \mathrm{CO}_{2}$ was liberated more abundantly under oxidative flooded conditions than reductive conditions. However, ${ }^{14} \mathrm{CO}_{2}$ produced was only about 2 to $3 \%$ of applied radioactivity after 20 days even under oxidative flooded conditions.

The degradation pathways of CNP postulated from the identified compounds are shown in Fig. 5. The degradation products of CNP in flooded soil may be present largely as complexes of the amino derivative. The reduction of nitro group to amino group may be the dominant reaction in the flooded soils, similar to the degradation of chlomethoxynil ${ }^{3)}$ and bifenox. ${ }^{4)}$ The amino derivative, however, may rapidly form complexes with soil particles. It has been reported that the reduction of the nitro group of $\mathrm{CNP}$ is due to soil microorgan- 


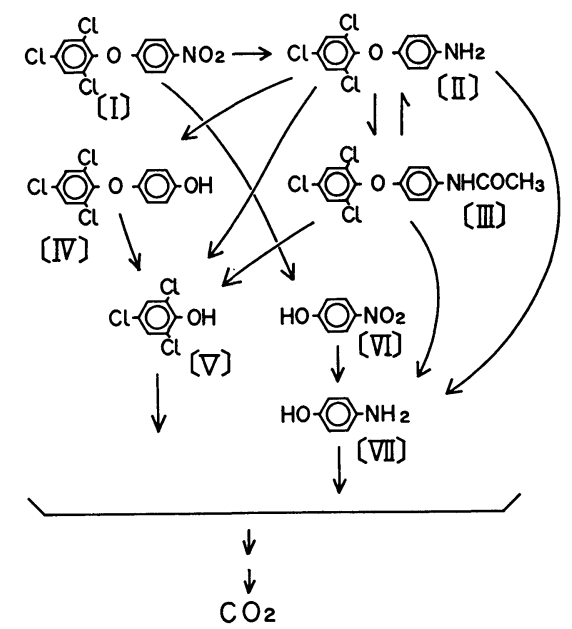

Fig. 5 Proposed pathways of CNP degradation in flooded soil.

Numerals in brackets correspond to the numerals in Fig. 2.

isms ${ }^{14)}$ and also occurs non-biologically by ferrous ions ${ }^{1)}$ produced under reductive soil conditions.

Diphenyl ether-, carbonilate-, acylanilide-, and phenylurea-herbicides are degraded to produce the aniline derivatives in soil. Acetylation is probably the major pathway of amino derivatives. $\mathrm{CNP}-\mathrm{NH}_{2}$ was converted to its acylamino derivatives by several soil microorganisms. ${ }^{14)}$ The amino derivatives of chlomethoxynil and bifenox were also acetylated only in non-sterilized soil but not in sterilized soil. On the other hand, propanil, ${ }^{15)} \mathrm{CMMP}^{16)}$ and other acylaniline compounds are easily hydrolyzed to the corresponding aniline derivatives in soil. Therefore, the acylation of $\mathrm{CNP}-\mathrm{NH}_{2}$ may also be a reversible reaction performed by soil microbes.

The nitro group was also substituted by hydroxy group. This hydroxy derivative is produced probably from $\mathrm{CNP}-\mathrm{NH}_{2}$ by a chemical reaction in which $\mathrm{CNP}-\mathrm{NH}_{2}$ reacts with nitrite in soil to form the diazo-compound that is decomposed to the hydroxy compound. ${ }^{14} C_{-}$ 2,4,6-Trichlorophenol was detected in the soil treated with ring $\mathrm{A}-{ }^{14} C-\mathrm{CNP}$ (Fig. 4). ${ }^{14} \mathrm{C}-\mathrm{p}-$ Nitrophenol and its reduced product, ${ }^{14} \mathrm{C}-p-$ aminophenol, were also produced in the soil treated with ring $\mathrm{B}-{ }^{14} \mathrm{C}-\mathrm{CNP}$, but these were detected only in trace amounts. This is prob- ably because $p$-nitrophenol produced was rapidly reduced to $p$-aminophenol, which is strongly adsorbed to soil particles to become unextractable with aqueous acetone in the same way as $\mathrm{CNP}-\mathrm{NH}_{2}$ described here and 3,4-dichloroaniline reported. ${ }^{17)}$ These phenolic compounds produced by cleavage of ether linkage of CNP were detected only in small or trace amounts compared with non-cleaved degradation products such as $\mathrm{CNP}-\mathrm{NH}_{2}, \mathrm{CNP}-\mathrm{NH}-$ $\mathrm{COR}$, and $\mathrm{CNP}-\mathrm{OH}$, under both reductive and oxidative conditions. These simple phenolic compounds may be decomposed rapidly to form aliphatic acids.

It has been reported that 3,4-dichloroaniline, a major degradation product of propanil, was transformed to $3,3^{\prime}, 4,4^{\prime}$-tetrachloroazobenzene, ${ }^{17)} \quad 3,3^{\prime}, 4,4^{\prime}$ - tetrachloroazoxybenzene, ${ }^{18,19)}$ 4-(3,4-dichloroanilino) $-3,3^{\prime}, 4^{\prime}$ - trichloroazobenzene, and 1,3-bis(3,4-dichlorophenyl)triazene ${ }^{20)}$ in the soil. In CNP degradation, however, such azo and related condensation products were not detected.

${ }^{14} \mathrm{CO}_{2}$ was liberated by cleavage of the ${ }^{14} \mathrm{C}$ benzene ring. Greater amount was produced under oxidative conditions, but the amounts did not exceed $0.3 \%$ of applied radioactivity after 20 days of incubation (Fig. 4). This may be because $\mathrm{CNP}-\mathrm{NH}_{2}$ transformed from $\mathrm{CNP}$ is present in relatively stable state against microbial attack by being adsorbed on soil particles. CNP degradation was slower and ${ }^{14} \mathrm{CO}_{2}$ liberation was more rapid in oxidative than reductive flooded soil. Therefore, it is presumed that $\mathrm{CNP}$ is retained for longer time in the surface layer than in the sub layer of field soil, and the degradation of benzene rings of $\mathrm{CNP}$ to $\mathrm{CO}_{2}$ occurs more rapidly in the surface layer where most part of the treated CNP is held in the field. These may result that $\mathrm{CNP}$ acts more effectively to weed seedlings in surface soil and is more safe to rice roots in deeper soil.

\section{ACKNOWLEDGEMENT}

The authors wish to thank Mitsui Toatsu Chemicals Inc. for providing radioactive $\mathrm{CNP}$ and many authentic chemicals. Thanks are also due to Professor K. Kumada and the members of our laboratory for their valuable advice and great assistance during the course of this study. 


\section{REFERENCES}

1) M. Oyamada \& S. Kuwatsuka: Abstr. 1974 Meet., Soc. Sci. Soil Manure, Japan, p. 8, 1974

2) J. P. Walter, E. F. Eastin \& M. E. Merkle: Week Res. 10, 165 (1970)

3) Y. Niki \& S. Kuwatsuka: Soil Sci. Plant Nutr. 22, 233 (1976)

4) H. Ohyama \& S. Kuwatsuka: J. Pesticide Sci. 3, (1978)

5) T. Toyama \& S. Tamagawa: Noyaku Kagaku (Japan) 3, 178 (1976)

6) T. Yamada, T. Nakamura \& S. Matsunaka: Abstr., 1974 Meet., Agric. Chem. Soc. Japan, p. 444,1974

7) R. Tatsukawa, K. Kusunoki \& T. Wakimoto: Abstr. 1973 Meet., Agric. Chem. Soc. Japan, p. 36, 1973

8) T. Yamada: Abstr., 1977 Meet., Pestic. Sci. Soc. (Japan), p. 142, 1977

9) H. Shimotori \& S. Kuwatsuka: J. Pesticide Sci. 3, 267 (1978)

10) H. Shimotori, S. Kuwatsuka \& T. Yoshimoto: under preparation

11) K. Kametani, T. Inoue \& K. Maruyama: Radioisotopes, 16, 41 (1967)

12) H. Shimotori \& S. Kuwatsuka: Abstr. Annu. Meet., Agric. Chem. Soc. Japan, p. 26, 1975

13) T. S. Hsu \& R. Bartha: Soil Sci. 118, 213 (1974)

14) M. Oyamada \& S. Kuwatsuka: Abstr., 1978 Meet., Pestic. Sci. Soc. (Japan), p. 123, 1978

15) H. Chisaka \& P. C. Kearney: J. Agric. Food Chem. 18, 854 (1970)

16) N. Shirakawa: Weed Res., Japan 10, 32 (1970)

17) R. Bartha: J. Agric. Food Chem. 16, 602 (1968)

18) P. C. Kearney \& J. R. Plimmer: J. Agric. Food Chem. 20, 584 (1972)
19) D. D. Kaufman, J. R. Plimmer, J. Iwan \& U. I. Klingebiel: J. Agric. Food Chem. 20, 916 (1972)

20) J. R. Plimmer, P. C. Kearney, H. Chisaka, J. B. Yount \& U. I. Klingebiel: J. Agric. Food Chem. 18, 859 (1970)

\section{要約}

\section{酸化的および還元的土壤条件下の湛水土壤中に おけるジフェニルェーテル系除草剤 CNP の 分解}

小山田正美，鍬塚昭三

室内実験により，好気的扔よび嫌気的湛水土塨中にお ける CNPの分解について，ベンゼン環のそれぞれを標 識した ${ }^{14} C-\mathrm{CNP}$ を用いて研究した. CNP は，好気的 （酸化的）湛水土㙵中では短い休止期間ののち 分解し， 半減期は 6 7 日であった。嫌気的（還元的）湛水土塨 中では急速に分解し, 半減期は $1 \sim 2$ 日であった. $t l c に$ よって同定された分解生成物は, CNP のニトロ基が ミノ基, アセチルアミノ基, 水酸基で置換された化合物 拉よび $2,4,6$-トリクロルフェノール，p-ニトロフェノ ール，p-アミノフェノールなどであった。 アセトン抽 出液中の分解物としてはアセチルアミノ体が最も多量に 生成し, 還元的湛水土塨中では，ホルミルアミノ体と推 定される微量の未同定化合物との合量で添加した放射能 の $15 \%$ に達した。 アセトン抽出物には集積する分解生 成物はみられなかった。有機溶媒で抽出できない土塨残 渣画分の放射能は添加量の $35 \sim 40 \%$ に達したが，大部 分は土塨粒子に強く結合した $\mathrm{CNP}$ アミノ体と推定し た、アミノ体が縮合して生成するアゾおよびアゾキシ化 合物などは検出されなかった。最終的にはベンゼン環も 開裂し， ${ }^{14} \mathrm{CO}_{2}$ の生成がみられるが，20日間の実験期 間中の ${ }^{14} \mathrm{CO}_{2}$ の生成は少なかった. $\mathrm{CNP}$ の減衰は還元 的条件下のほうが速いが， ${ }^{14} \mathrm{CO}_{2}$ の生成は酸化的条件下 のほうが速かった。 